IZA DP No. 5354

Immigrants' Employment Outcomes

over the Business Cycle

Pia Orrenius

Madeline Zavodny

December 2010 


\title{
Immigrants' Employment Outcomes over the Business Cycle
}

\author{
Pia Orrenius \\ Federal Reserve Bank of Dallas \\ and IZA \\ Madeline Zavodny \\ Agnes Scott College \\ and IZA
}

\section{Discussion Paper No. 5354 \\ December 2010}

\author{
IZA \\ P.O. Box 7240 \\ 53072 Bonn \\ Germany \\ Phone: +49-228-3894-0 \\ Fax: +49-228-3894-180 \\ E-mail: iza@iza.org
}

\begin{abstract}
Any opinions expressed here are those of the author(s) and not those of IZA. Research published in this series may include views on policy, but the institute itself takes no institutional policy positions.

The Institute for the Study of Labor (IZA) in Bonn is a local and virtual international research center and a place of communication between science, politics and business. IZA is an independent nonprofit organization supported by Deutsche Post Foundation. The center is associated with the University of Bonn and offers a stimulating research environment through its international network, workshops and conferences, data service, project support, research visits and doctoral program. IZA engages in (i) original and internationally competitive research in all fields of labor economics, (ii) development of policy concepts, and (iii) dissemination of research results and concepts to the interested public.
\end{abstract}

IZA Discussion Papers often represent preliminary work and are circulated to encourage discussion. Citation of such a paper should account for its provisional character. A revised version may be available directly from the author. 
IZA Discussion Paper No. 5354

December 2010

\section{ABSTRACT \\ Immigrants' Employment Outcomes over the Business Cycle}

Immigrants have figured prominently in U.S. economic growth for decades, but the recent recession hit them hard. Immigrants' labor market outcomes began deteriorating even before the recession was officially underway, largely as a result of the housing bust. An analysis of employment and unemployment rates over the past 15 years shows that immigrants' labor market outcomes are more cyclical than those of natives. The greater cyclicality of immigrants' employment and unemployment is concentrated among less-educated immigrants, but college-educated immigrants nonetheless have more cyclically-sensitive employment outcomes than college-educated natives.

JEL Classification: J21, J61, J64, E32

Keywords: business cycle, recession, employment, immigrants

Corresponding author:

Pia Orrenius

Research Department

Federal Reserve Bank of Dallas

2200 N. Pearl Street

Dallas, TX 75201

USA

E-mail: Pia.Orrenius@dal.frb.org

\footnotetext{
* The views expressed herein do not necessarily reflect the views of the Federal Reserve Bank of Dallas or the Federal Reserve System. We thank Michael Nicholson for excellent research assistance. This paper is a revised and expanded version of our report "Tied to the Business Cycle: How Immigrants Fare in Good and Bad Economic Times" for the Migration Policy Institute, available online at http://www.migrationpolicy.org/pubs/orrenius-Nov09.pdf.
} 


\section{Immigrants’ Employment Outcomes over the Business Cycle}

\section{Introduction}

The United States is emerging from the deepest downturn the country has experienced since the Great Depression. By the time the unemployment rate peaked in October 2009, the number of unemployed persons had risen by 7.9 million since the “Great Recession” began in December 2007. ${ }^{1}$ All demographic groups experienced job losses, but some groups were more adversely affected than others. Repeating the pattern of most previous downturns, the recession's impact has been worst for low-education and minority workers.

One group that has been particularly hard hit is immigrants. Immigrants comprise about 13 percent of the U.S. population and an even larger share-over 15 percent—of the labor force. ${ }^{2}$ Between the end of 2006 and the first half of 2009, the unemployment rate among immigrants rose from a low of 3.4 percent to a high of 9.2 percent, and their employment rate dropped by 4.6 percentage points. In contrast, during that period the unemployment rate among natives rose from a low of 4.1 percent to a high of 8.3 percent, and their employment rate fell by 3.3 percentage points. ${ }^{3}$ Immigrants' earnings also fell much more steeply than natives’ wages from 2009 to 2010 (Kochhar 2010).

Immigrants are particularly sensitive to economic downturns because of their relatively low average skill levels. Immigrants make up almost two-fifths of workers who do not have a high school diploma or equivalent and three-quarters of workers who have completed at most eighth grade. When the economy slows, employers look to shed their least productive employees first. Employers tend to invest less in training low-skilled workers and therefore have less

\footnotetext{
${ }^{1}$ See U.S. Department of Labor, Bureau of Labor Statistics, “Employment Situation Summary” (news release, December 4, 2009), http://www.bls.gov/news.release/empsit.nr0.htm.

${ }^{2}$ We use the terms 'immigrant' and 'foreign-born' interchangeably in this paper.

${ }^{3}$ All statistics presented in this paper are authors' calculations from Current Population Survey outgoing rotation group data unless indicated otherwise.
} 
incentive to try to keep them when laying off workers. Less-skilled workers may also be displaced by high-skilled workers who move down the skill chain during a recession (Devereux 2004). While this pattern affects both low-skilled immigrants and natives, low-skilled immigrants, particularly recent arrivals, face additional difficulties. Over one-half of all U.S. immigrants and three-quarters of those who have not completed high school report that they cannot speak English very well. Immigrants also tend to have less social capital, or fewer connections and less knowledge about labor markets, than low-skilled natives. Such difficulties are compounded by a lack of legal status for some 8 million unauthorized immigrant workers in the U.S.

While immigrants' relatively low skill levels make the foreign born particularly vulnerable during recessions, other factors may partly offset this effect. Immigrants tend to be more mobile than natives, both geographically and across industries and occupations (Borjas 2001). If immigrants are quicker to search for and find alternative employment than natives, their unemployment spells may be shorter. In addition, immigrant inflows slow during recessions, particularly among unauthorized and employment-based legal immigrants, and some immigrants return home as their economic prospects worsen. Both of these behaviors reduce the competition for jobs among immigrants during downturns. They also dampen the cyclicality of the immigrant employment and unemployment rates.

Previous research suggests that immigrants' vulnerabilities tend to outweigh these advantages. Several studies conclude that immigrants' labor market outcomes are more sensitive than natives' outcomes to business cycle fluctuations in the U.S. and in several other countries. For example, employment and unemployment appear to be more sensitive to changes in the national unemployment rate among male immigrants than among male natives in the U.S. 
(Chiswick, Cohen and Zach 1997). Immigrants' hourly wages also are more sensitive than natives' wages to changes in state-level unemployment rates in the U.S. (Bratsberg, Barth and Raaum 2006). A similar pattern holds for earnings in Norway (Barth, Bratsberg and Raaum 2004). Within education groups, unemployment rates—but not earnings—are more responsive to the business cycle among immigrants than among natives in Germany and in the United Kingdom (Dustmann, Glitz and Vogel 2009). In the U.S., in contrast, employment tends to be more cyclically sensitive among natives than among immigrants within education and race/ethnicity groups, whereas the opposite pattern holds for earnings (Borjas 2005).

This study provides additional, recent evidence on whether labor market outcomes are more sensitive among immigrants than among U.S. natives. Using data from 1994 through the first half of 2009, we find that immigrants' employment and unemployment rates display excess cyclicality relative to natives. This is true for comparisons relative to all natives and relative to natives with the same level of educational attainment. After showing that this is true for business cycles at both the national and state levels, we turn to a brief discussion of policy implications.

\section{Data}

Until recently, there was limited opportunity to study immigrants' labor market outcomes over the business cycle in the U.S. The necessary data—regular surveys that ask individuals about economic outcomes and foreign birth—only began to become available as of $1994{ }^{4}$ Economists then had to wait until 2001 to observe a recession, which was relatively mild. The considerably more severe and prolonged downturn that began in late 2007 and ended in June

\footnotetext{
${ }^{4}$ The 1980, 1990 and 2000 censuses all occurred near business-cycle peaks and so do not provide the needed variation to study business cycle effects.
} 
2009 thus provides an excellent opportunity to examine how immigrants fare relative to natives over the business cycle.

All data used here are from the Current Population Survey outgoing rotations group data. When examining the entire labor force, we include all individuals age 16 and older. When examining specific education groups, we include only individuals age 25 and older in order to capture completed education levels. Observations are weighted using the composite weights.

We examine only employment and unemployment because there already is a relatively extensive wage-curve literature that examines the effect of macroeconomic conditions on earnings, including Bratsberg, Barth and Raaum’s (2006) comparison of immigrants and natives. We conduct both an aggregate analysis that examines trends and cycles in employment and unemployment rates and an individual-level analysis that examines the effect of the business cycle on employment outcomes, controlling for individual characteristics. For the aggregate analysis, we used the composite weights to create seasonally adjusted quarterly employment and unemployment rates.

\section{Background on Immigrant and Native Labor Market Outcomes}

Viewed over the course of two expansions and two recessions, trends in immigrant and native employment and unemployment rates over the last 15 years provide insight into how these two groups fare over the business cycle. Employment rates, which measure employed workers as a share of the noninstitutionalized civilian population, are typically procyclical, increasing during expansions and falling during recessions. Unemployment rates, which measure the unemployed as a share of the labor force, are typically countercyclical. 
Figure 1 shows the employment rates for immigrants and natives from the first quarter of 1994 through the second quarter of 2009. The shaded portions indicate the two recessions during this period: the high-tech bust in 2001 and the more recent housing bust/financial crisis. ${ }^{5}$ The figure suggests that the immigrant employment rate is more procyclical than the native rate. The immigrant employment rate skyrocketed by over 4 percentage points during the 1990s boom while the native employment rate inched upward about 1 percentage point. Employment rates for both groups fell during the 2001 recession, but by 2003 the immigrant employment rate surpassed the native employment rate and remained consistently higher. The immigrant employment rate reached a series high of over 66 percent in early 2007, while the native employment rate never returned to its pre-2000 rates. Instead, it remained largely flat during the 2000s economic expansion and then fell with the onset of the recession in late 2007. Since then, the immigrant employment rate has fallen more precipitously than the native rate.

Figure 2 suggests a similar pattern with regard to unemployment rates. During the 1990s expansion, the immigrant unemployment rate fell more than the native rate. After rising in the early 2000s, the immigrant unemployment rate fell to 3.4 percent in late 2006, its lowest point over the 15-year period. The native unemployment rate did not fall as much during the 2000s expansion and actually bottomed out at 3.8 percent in the fourth quarter of 2000 . The immigrant unemployment rate started rising earlier and faster than the native unemployment rate as the economy moved into the recession in late 2007.

Differences in educational attainment may help explain these patterns. Natives are concentrated in the middle to high end of the education distribution while immigrants are concentrated at the low and high ends. Based on 2009 CPS data, roughly equal shares of adult

\footnotetext{
${ }^{5}$ Because we use quarterly data, the figures here show the 2001 recession—officially from March 2001 to November 2001, according to the NBER—as occurring from the second through the fourth quarter 2001. The recent recession is shown as beginning in the first quarter of 2008 instead of NBER's official start date of December 2007.
} 
natives have a high school diploma (32 percent), some college (28 percent), and a bachelor’s degree or higher (30 percent). Only 10 percent have not completed high school. Immigrants are less likely to be in the middle of the education distribution; about 25 percent have a high school diploma and 15 percent some college. In contrast, 30 percent of immigrants have no high school diploma, and 29 percent have a bachelor's degree or higher. Although educational attainment increased among both immigrants and natives during the last 15 years, natives have experienced a slightly faster pace of increase.

The most dramatic difference in employment and unemployment rates is between immigrants and natives who have not completed high school. As the top left panel of Figure 3 shows, the employment rate among less-educated immigrants ranged between 55 and 60 percent during 1994-2009, over 20 percentage points higher than the employment rate among lesseducated natives. Correspondingly, less-educated natives had higher unemployment rates than immigrants during the 2000s (Figure 4). These gaps widened during the housing boom, which benefited less-educated immigrants more than less-educated natives. Immigrants with a high school diploma but no college education also outperformed similarly-educated natives in terms of employment during the 2000s.

While less-educated immigrants tend to substantially outperform less-educated natives in terms of employment and unemployment, the opposite is the case among the highly educated. College-graduate immigrants tend to have slightly lower employment rates and higher unemployment rates than similarly educated natives. In the first half of 2009, for example, college-educated immigrants averaged unemployment rates close to 6 percent, quite a bit higher than the 4 percent rate for college-educated natives. 


\section{Immigrant and Native Sensitivity to the Business Cycle}

We now turn to a more formal analysis of whether labor market outcomes are more cyclical among immigrants than natives and use several methods to examine this issue. We first decompose the data into trend and cyclical components using the Hodrick-Prescott (HP) filter. ${ }^{6}$ We compare the cyclical components, which are short-run fluctuations around the long-run trend, of aggregate immigrant and native labor market outcomes by correlating them with GDP growth. We then also examine the relationship between labor market outcomes and the business cycle in a regression framework with individual-level data.

Figure 5 shows the cyclical component of the immigrant and native employment rates. The vertical axis measures the percentage points by which each group’s employment rate in a given quarter was above or below its trend over the 15 year period. The impact of the two recessions is apparent: both native and immigrant employment rates fell below their long-run trends (below the zero line) during the downturns. Employment rates remained low for several years after the 2001 recession ended, a period that has been frequently characterized as a jobless recovery.

Figure 5 also indicates that the immigrant employment rate experiences greater volatility than the native employment rate. The magnitude of the swings in the series is considerably larger for immigrants — the standard deviation of the cyclical component of the immigrant employment rate is 0.9 percentage points compared with 0.5 percentage points for natives. This greater volatility appears to be caused by greater sensitivity of immigrant employment to the business cycle. The immigrant cyclical component is above that of natives during booms (1996 to 1998, at the end of 2000, and during 2005 to 2007) and below that of natives during economic troughs (in

\footnotetext{
${ }^{6}$ We use a smoothing parameter value of 1600 .
} 
2002 and 2008 to 2009). Immigrants' employment rate rises higher in booms and sinks lower in busts.

Like the employment rate, the unemployment rate is more volatile among immigrants than natives. Figure 6 shows the cyclical component of the unemployment rates for natives and immigrants. Again, the standard deviation of the cycle is larger for immigrants than for natives, at 0.9 percentage points for immigrants versus 0.6 percentage points for natives. These deviations are particularly large before and after recessions, the very high and low points of economic activity. The 2001 recession shows this clearly, with the immigrant unemployment rate first dipping much further below its trend than the native rate and then spiking much higher above its trend soon after the recession's end. Despite registering unemployment well above the long-term trend in the wake of the high-tech bust of 2001, the immigrant unemployment rate recovered quickly. The housing boom provided a notable boost to job opportunities among immigrant workers during the 2000s expansion.

If immigrants' labor market outcomes are indeed more sensitive to swings in the business cycle, then they should be more strongly correlated with the growth rate of gross domestic product (GDP) than are natives' labor market outcomes. As an initial foray into examining this possibility, Table 1 presents the simple correlation between quarterly GDP growth rates and the cyclical component of the employment rate and the unemployment rate series for immigrants and natives overall and by educational attainment. We focus on the cyclical component instead of the raw data because we are examining the correlation with GDP growth, not levels. Using detrended labor market outcomes is important in this comparison because the employment and unemployment trends among immigrants and natives are different over this period (as can be clearly seen in Figures 1 and 2). 
The correlations indicate that immigrants' labor market outcomes are indeed more tied to the business cycle. The difference is most striking for employment, shown in the top panel of Table 1. The correlation between the GDP growth rate and the cyclical component of the employment rate for all immigrants is 0.26 versus 0.14 for natives. Looking by education, the correlation is strongest among immigrants who do not have a high school diploma at 0.32 . The opposite is true among natives - the correlation between GDP growth and the cyclical component of the employment rate is weakest among the least-educated at 0.02. A similar pattern holds among college graduates, with the correlation between real GDP growth and the cyclical component of the employment rate more than twice as large among immigrants with a Bachelor's degree or higher as among natives (0.24 and 0.11 , respectively).

In contrast to the results for employment rates, the correlation between real GDP growth and the cyclical component of the unemployment rate is similar among immigrants and natives. As the bottom panel of Table 2 reports, the simple correlation between the real GDP growth rate and the cyclical component of the unemployment rate is -0.25 for immigrants and -0.22 for natives overall. However, the correlation is considerably stronger among immigrants who do not have a high school diploma than among natives (-0.22 and -0.12 , respectively).

The correlations thus suggest that employment is more cyclically-sensitive among immigrants than among natives overall. Why this result does not carry over to unemployment is an interesting question. It is possible that the labor force adjusts more readily in the case of immigrants than natives. One possible explanation is that unemployed immigrants have less incentive to remain in the labor force than natives because they are often ineligible for unemployment benefits. Also, unemployed immigrants are more likely than natives to move within the U.S. or even leave the country entirely when jobs are relatively scarce, dampening the 
correlation between the immigrant unemployment rate and the business cycle. In addition, the duration of immigrants' unemployment spells may be less variable over the business cycle, both because of greater mobility and because immigrants may search harder for jobs and have lower expectations regarding job amenities, such as a desirable location, pleasant working conditions, and fringe benefits, than natives do.

Immigrants with some college education but not a Bachelor's degree appear to be an anomalous group in Table 1. The reasons for this are unclear. These immigrants may have credentials that transfer particularly poorly into the U.S. labor market. Alternatively, immigrants in this group may be particularly heterogeneous. Immigrants with a particularly large variety of education levels and credentials may fall into that education level, resulting in little correlation between real GDP growth and the cyclical components of their employment and unemployment rates.

To further understand immigrant-natives differences, we turn to regressions that allow us to compare the sensitivity of immigrants' and natives' labor market outcomes to the business cycle, controlling for individual-level characteristics.

\section{Regression Model}

We estimate the following simple linear probability model of individuals’ labor market outcome (employment or unemployment status).

Labor market outcome $_{\text {ist }}=\alpha+\beta_{1}$ Business Cycle $_{s t}+\beta_{2}$ Demographics $_{i}+\beta_{3}$ Time $_{t}+$

$$
\beta_{4} \text { TimeSquared }_{t}+\beta_{5} S_{s}+\beta_{6} Q_{t}+\varepsilon_{\text {ist }} \text {, }
$$


When examining employment, we include all individuals 16 and older in the population. When examining unemployment, we only include individuals 16 and older in the labor force. We focus on the relationship between employment or unemployment status and one of two measures of the business cycle: the quarterly growth rate in real GDP or the quarterly growth rate in state real personal income. ${ }^{7}$ The first measure captures the national business cycle while the second captures changes in state-level macroeconomic conditions. ${ }^{8}$ We include only one measure in the regressions because of multicollinearity between the two variables.

We estimate the linear probability regressions for immigrants and natives overall and then by education. As with the aggregate analysis, the overall results include all individuals age 16 and older while the education results only include individuals age 25 and older. In addition to a measure of the business cycle, the regressions include an indicator variable for females, a quartic in age, state dummy variables, a linear time trend and its square, and quarter dummy variables to control for any seasonal effects.

\section{Results}

Employment and unemployment likelihoods tend to be more tied to the national business cycle among immigrants than among natives. As the top panel of Table 2 shows, the effect of real GDP growth on employment is more than three times larger among all immigrants than among all natives ( 0.542 versus 0.166$)$. Turning to unemployment, the effect of GDP growth is almost twice as large on all immigrants as on all natives (-0.665 versus -0.341). The fact that the immigrant-native difference is smaller for unemployment than for employment echoes the

\footnotetext{
${ }^{7}$ Growth in GDP and personal income are calculated as the first difference of logged values.

${ }^{8}$ Unlike some previous research, we do not use unemployment rates as a measure of the business cycle since they are mechanically related to the dependent variable in CPS data, particularly at the state level. The advantage of unemployment rates is that they are available monthly, unlike national GDP and state personal income.
} 
findings from the correlations above. Nonetheless, the regressions do indicate that the employment and unemployment probabilities are more closely tied to the business cycle among immigrants than among natives overall.

This difference in cyclical sensitivity is not simply a result of lower levels of education among immigrants. As the other coefficients in Table 2 show, the same result holds within most education groups. Among people who do not have a high school diploma, for example, the effect of stronger GDP growth on employment is more than five times as large among immigrants as among natives ( 0.588 versus 0.115 , with the latter not even significantly different from zero). Within each education group except for the some college group, immigrants' labor market outcomes are more sensitive to the national business cycle.

The results using the growth rate of state-level real personal income as a measure of the business cycle are fairly similar to the national results, as can be seen in Table 3. Employment and unemployment are more closely tied to the growth rate of state real personal income among immigrants than among natives. This result holds overall and within each education group, including the some college group.

The sensitivity of unemployment likelihood to the state business cycle declines monotonically across education groups for both immigrants and natives. More educated workers are less vulnerable to the business cycle in terms of unemployment prospects regardless of their nativity. Surprisingly, a similar result does not hold for employment prospects. The fact that more-educated workers are not necessarily more sheltered from the business cycle in terms of employment prospects is an intriguing finding worthy of more research. This could be an artifact of the two most recent recessions since both impacted severely sectors with relatively high 
education levels (the technology sector in 2001 and the financial sector in the recent recession), or it could indicate structural changes in the labor market.

\section{Discussion}

There have been improvements in immigrant outcomes over the past 15 years. Economic booms have hastened immigrants' progress while the recent recession has slowed it. Recessions harm employment prospects and raise unemployment. This occurs among both immigrants and natives, but the effect tends to be larger among immigrants, particularly the least-educated.

Immigrants' economic outcomes tend to be more sensitive to the business cycle than those of natives, particularly with regard to employment. This is true overall as well as within most education groups, indicating that low average levels of education attainment cannot fully account for the more pronounced cyclicality of immigrants' labor market outcomes.

Immigrants' greater vulnerability to the business cycle raises an interesting conundrum for public policies assisting people during downturns. Unemployment insurance (UI), the main program aimed at helping workers ride out recessions, covers only a minority of unemployed workers. UI programs have a large number of exclusions that disproportionately affect low-wage workers, who are more likely to move between jobs, hold several part-time jobs, or be selfemployed. Many unemployed immigrants are therefore ineligible for UI benefits, and all unauthorized immigrants are categorically ineligible.

Other transfer programs also may be ineffective at helping immigrants during downturns. Many immigrants are ineligible for benefits because they are unauthorized or have not spent sufficient time in the United States. Also, immigrants may be reluctant to apply for benefits because they are concerned about jeopardizing an application for naturalization or a green card 
or revealing a family member's unauthorized status. In addition, immigrant households are more likely to be among the working poor than native households, which makes them ineligible for many transfer programs. Low-education immigrants are much more likely to work and less likely to be unemployed than less-educated natives, even during recessions.

Reforming U.S. immigration policy is one way to help mitigate immigrants’ vulnerability to the business cycle. Immigrant admissions could be restructured to explicitly tie admissions to the business cycle or to make employment-based flows a larger share of all admissions. Either way, inflows would be more cyclical, falling during recessions and rising during expansions. This would better sync immigration with economic growth, lessening the burden on competing workers and reducing the need for expanded safety-net programs during economic downturns. Making immigration policy more responsive to the business cycle requires no outlay of funds and would benefit immigrants already present in the United States and possibly natives as well. 


\section{References}

Borjas, George J. (2001). "Does Immigration Grease the Wheels of the Labor Market?” Brookings Papers on Economic Activity 1: 69-119.

Borjas, George J. (2005). “Wage Trends among Disadvantaged Minorities.” University of Michigan National Poverty Center Working Paper 05-12.

Barth, Erling, Bernt Bratsberg, and Oddbjørn Raaum (2004). "Identifying Earnings Assimilation of Immigrants under Changing Macroeconomic Conditions.” Scandinavian Journal of Economics 106: 1-22.

Bratsberg, Bernt, Erling Barth, and Oddbjørn Raaum (2006). "Local Unemployment and the Relative Wages of Immigrants: Evidence from the Current Population Surveys.” Review of Economics and Statistics 88: 243-263.

Chiswick, Barry R., Yinon Cohen, and Tzippi Zach (1997). “The Labor Market Status of Immigrants: Effects of the Unemployment Rate at Arrival and Duration of Residence.” Industrial and Labor Relations 50: 289-303.

Devereux, Paul J. (2004). “Cyclical Quality Adjustment in the Labor Market.” Southern Economic Journal 70: 600-615.

Dustmann, Christian, Albrecht Glitz, and Thorsten Vogel (2009). "Employment, Wages, and the Economic Cycle: Differences between Immigrants and Natives.” IZA Discussion Paper No. 4432.

Kochhar, Rakesh (2010). "After the Great Recession: Foreign Born Gain Jobs; Native Born Lose Jobs.” Pew Hispanic Center, Washington, D.C. 
Figure 1. Employment Rates by Nativity, 1994-2009

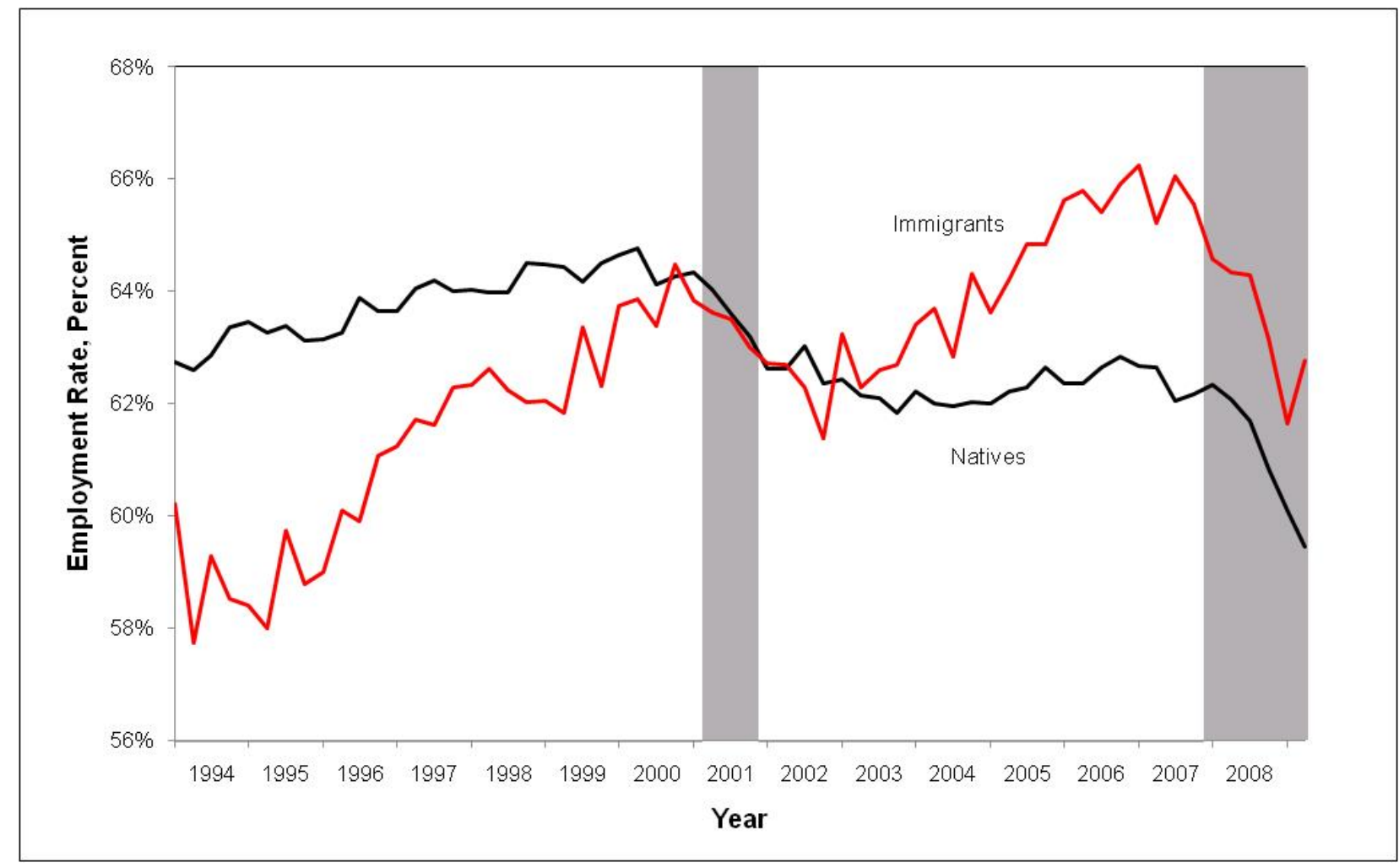

Note: Shown are seasonally adjusted quarterly data for first quarter 1994 to second quarter 2009. Recessions are shown as shaded areas.

Source: Authors' calculations from U.S. Census Bureau, Current Population Survey, January 1994 to June 2009. 
Figure 2. Unemployment Rates by Nativity, 1994-2009

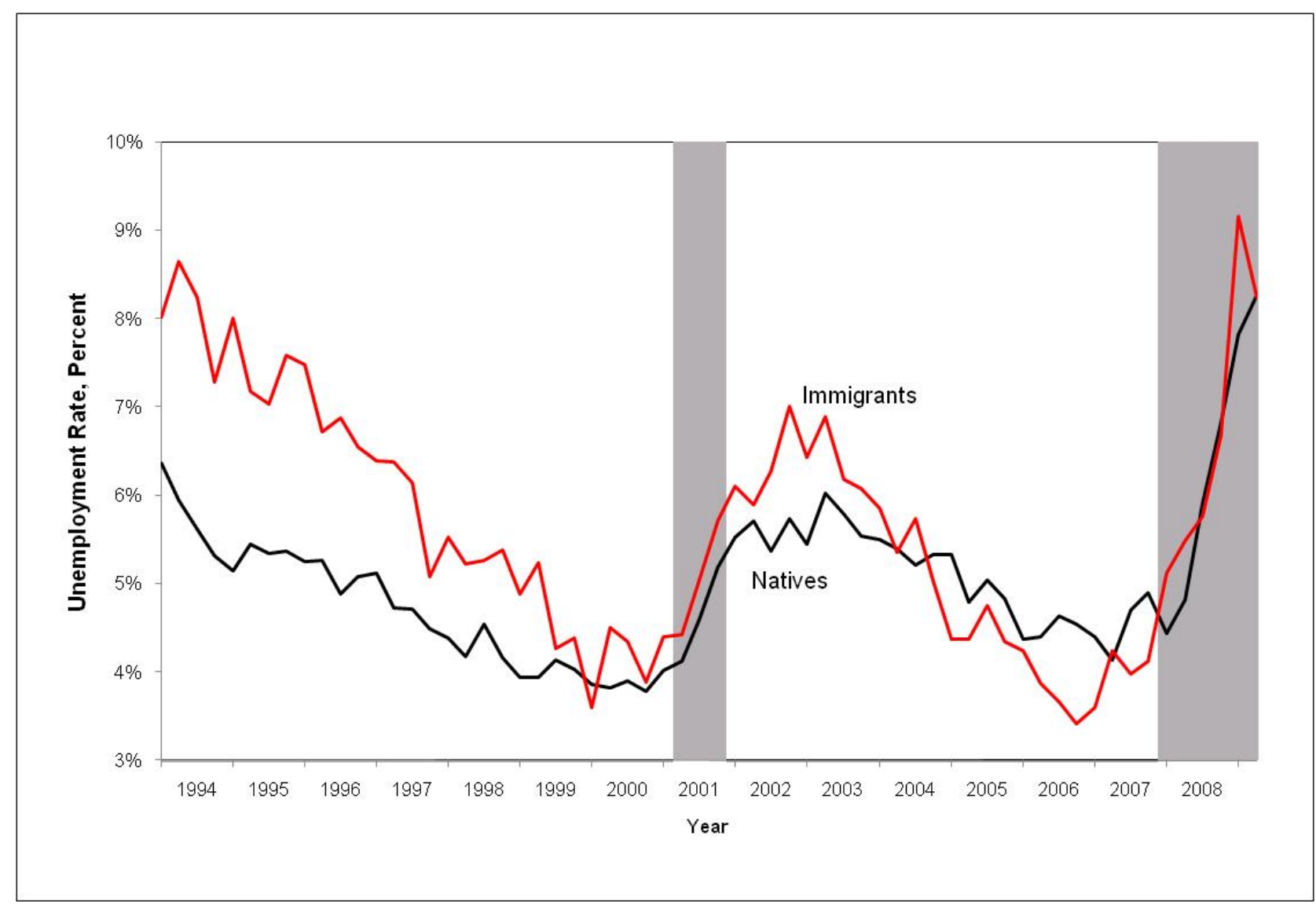

Note: Shown are seasonally adjusted quarterly data for first quarter 1994 to second quarter 2009. Recessions are shown as shaded areas.

Source: Authors' calculations from U.S. Census Bureau, Current Population Survey, January 1994 to June 2009. 
Figure 3. Employment Rates by Nativity and Education, 1994-2009

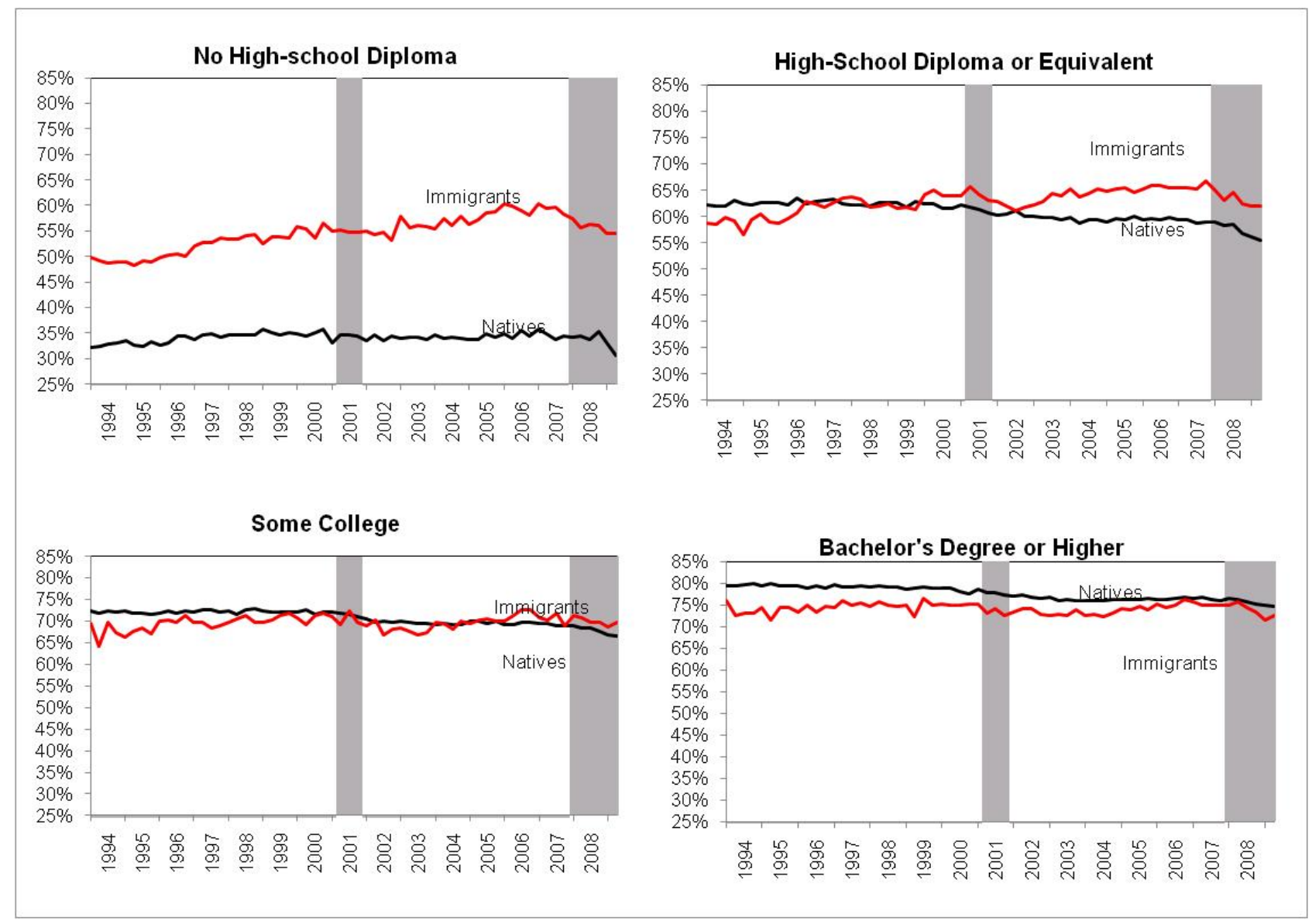

Note: Shown are seasonally adjusted quarterly data for first quarter 1994 to second quarter 2009. Data include only individuals age 25 and older. Recessions are shown as shaded areas. Source: Authors' calculations from U.S. Census Bureau, Current Population Survey, January 1994 to June 2009. 
Figure 4. Unemployment Rates, by Nativity and Education, 1994-2009

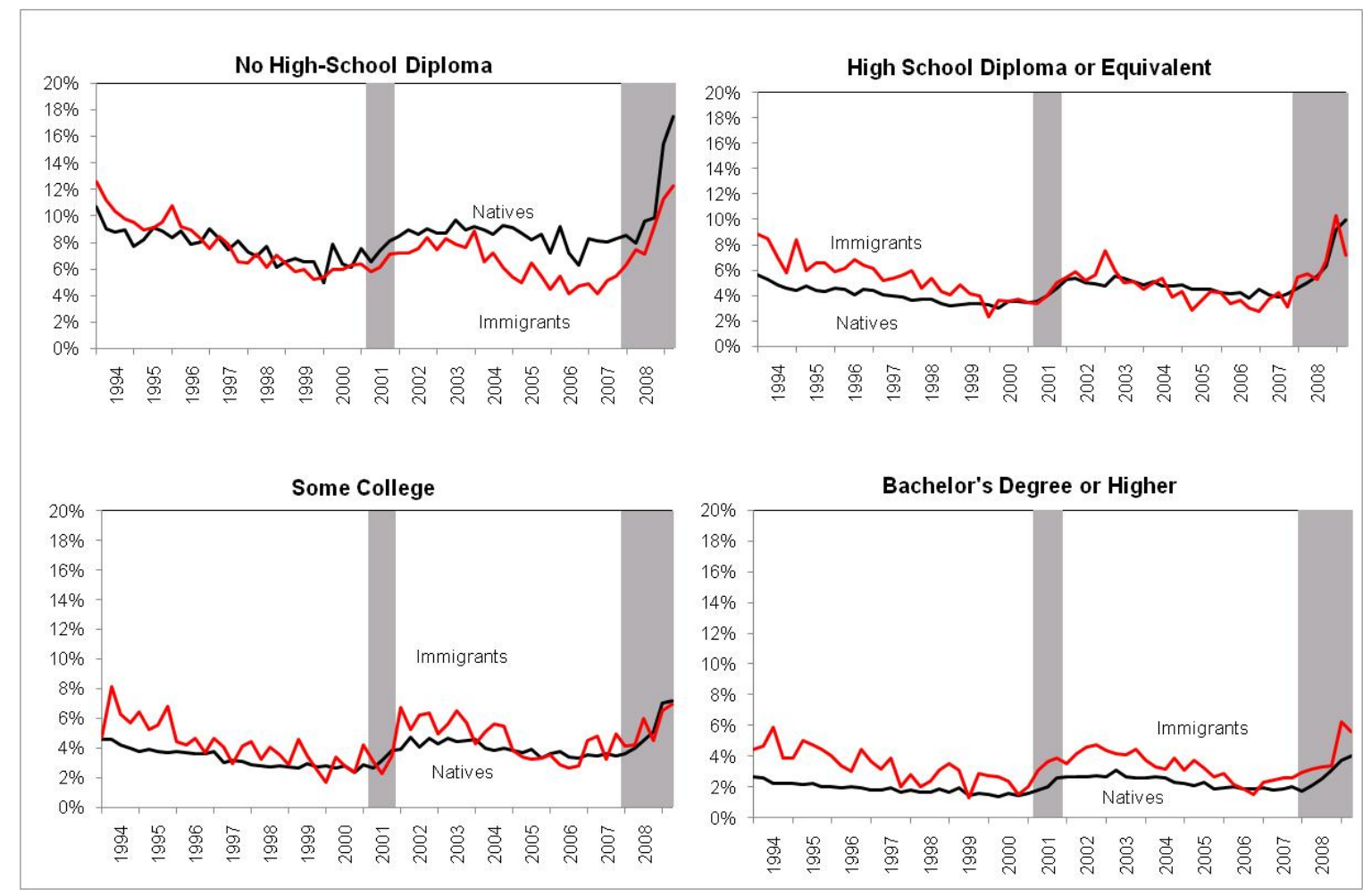

Note: Shown are seasonally adjusted quarterly data for first quarter 1994 to second quarter 2009. Data include only individuals age 25 and older. Recessions are shown as shaded areas. Source: Authors' calculations from U.S. Census Bureau, Current Population Survey, January 1994 to June 2009. 
Figure 5. Short-Run Fluctuations in Employment Rates by Nativity, 1994-2009

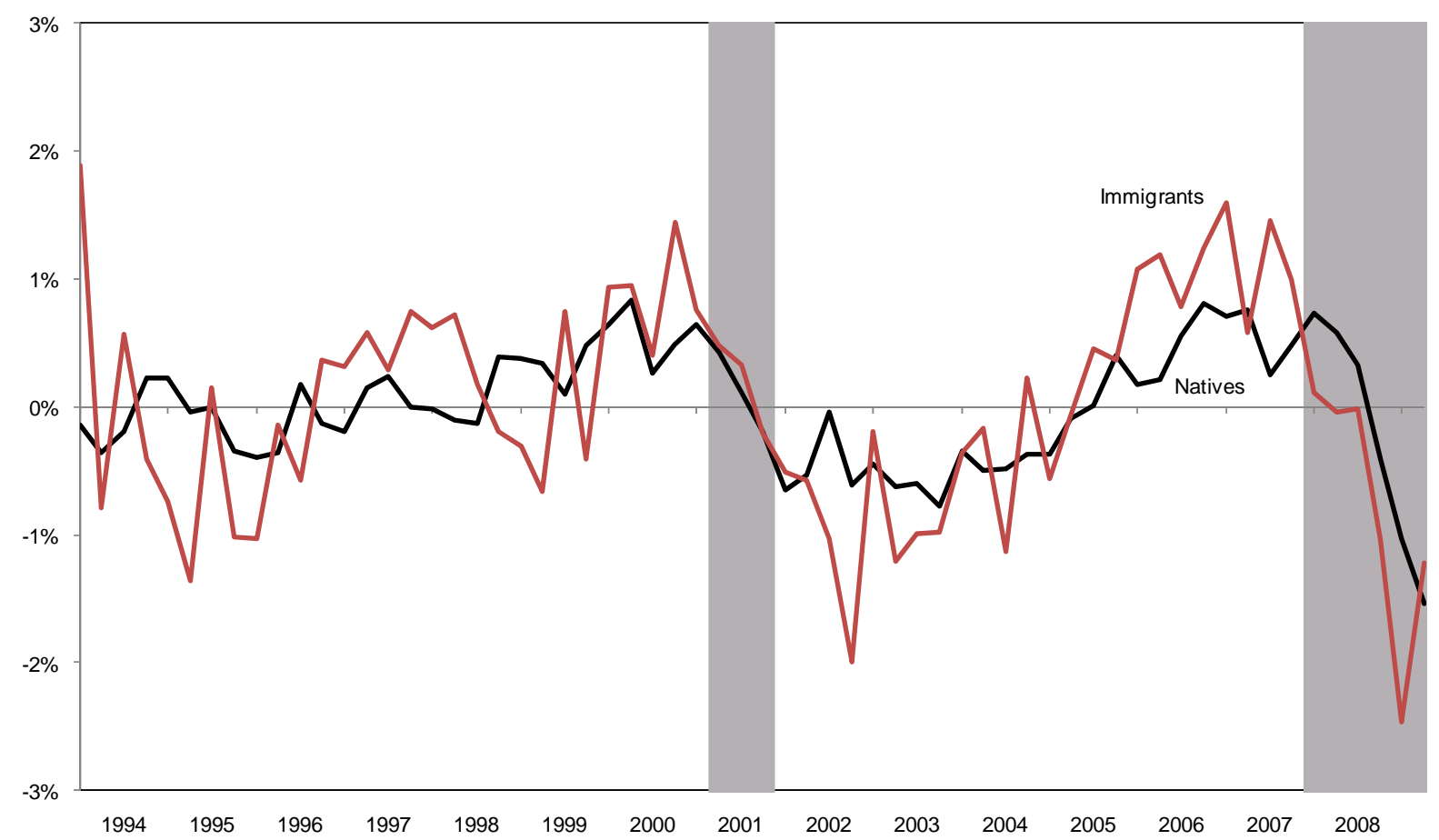

Note: Shown are the cyclical components after applying the Hodrick-Prescott filter to employment rates. Recessions are shown as shaded areas. Data are seasonally adjusted. Source: Authors' calculations from U.S. Census Bureau, Current Population Survey, January 1994 to June 2009. 
Figure 6. Short-Run Fluctuations in Unemployment Rates by Nativity, 1994-2009

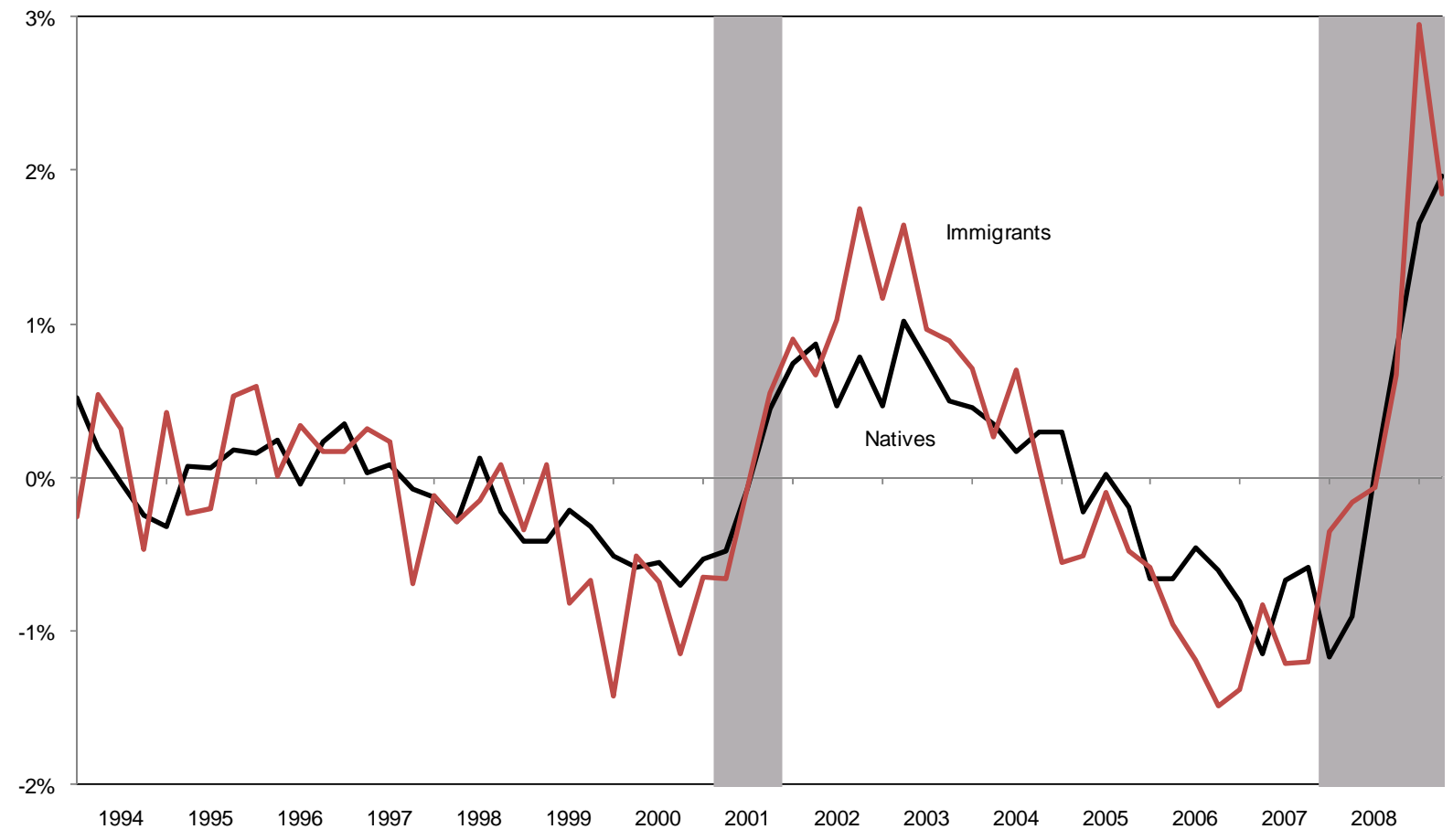

Note: Shown are the cyclical components after applying the Hodrick-Prescott filter to unemployment rates. Recessions are shown as shaded areas. Data are seasonally adjusted. Source: Authors' calculations from U.S. Census Bureau, Current Population Survey, January 1994 to June 2009. 
Table 1. Correlation between GDP Growth Rate and Cyclical Components of Labor Market Outcomes, by Nativity and Education

\begin{tabular}{lcc} 
& Immigrants & Natives \\
\hline Employment rate & 0.26 & 0.14 \\
All & 0.32 & 0.02 \\
No high school diploma & 0.18 & 0.19 \\
High school diploma only & -0.02 & 0.17 \\
Some college & 0.24 & 0.11 \\
Bachelor's degree & & \\
Unemployment rate & & \\
All & -0.25 & -0.22 \\
No high school diploma & -0.22 & -0.12 \\
High school diploma only & -0.23 & -0.22 \\
Some college & -0.05 & -0.22 \\
Bachelor's degree & -0.20 & -0.22 \\
\hline
\end{tabular}

Note: Shown is the correlation between changes in real GDP and the cyclical component of the labor market outcome (employment or unemployment rate) by nativity and education. See text for details. Data are from the first quarter of 1994 through the second quarter of 2009. The "all" rows include individuals age 16 and older, and rows by education include only individuals age 25 and older. 
Table 2. Regression Estimates of the Sensitivity of Labor Market Outcomes among Immigrants and Natives to the National Business Cycle

\begin{tabular}{lcc} 
& Immigrants & Natives \\
\hline Employed & $0.542^{* *}$ & $0.166^{* *}$ \\
All & $(0.106)$ & $(0.038)$ \\
No high school diploma & $0.588^{* *}$ & 0.115 \\
High school diploma only & $(0.199)$ & $(0.117)$ \\
& $0.554^{*}$ & $0.309^{* *}$ \\
Some college & $(0.220)$ & $(0.070)$ \\
& 0.091 & $0.185^{*}$ \\
Bachelor's degree & $(0.276)$ & $(0.074)$ \\
& $0.731^{* *}$ & $0.247^{* *}$ \\
Unemployed & $(0.202)$ & $(0.067)$ \\
All & & \\
No high school diploma & $-0.665^{* *}$ & $-0.341^{* *}$ \\
High school diploma only & $(0.071)$ & $(0.025)$ \\
& $-0.781^{* *}$ & $-0.414^{* *}$ \\
Some college & $(0.164)$ & $(0.131)$ \\
Bachelor's degree & $-0.732^{* *}$ & $-0.483^{* *}$ \\
& $(0.145)$ & $(0.045)$ \\
& -0.199 & $-0.353^{* *}$ \\
& $(0.165)$ & $(0.043)$ \\
& $-0.468^{* *}$ & $-0.268^{* *}$ \\
& $(0.107)$ & $(0.032)$ \\
\hline
\end{tabular}

$* p<0.05 ; * * p<0.01$

Note: Shown are estimated coefficients on the growth rate of real GDP in linear probability regressions. The samples for the top panel are the population age 16 and older for all or age 25 and older for education groups. The samples in the bottom panel are the labor force age 16 and older for all or age 25 and older for education groups. Each entry is from a separate regression. Regressions also include a linear time trend and its square, a quartic in age, an indicator for female, and state and quarter indicator variables. The (unweighted) number of observations is 533,582 for immigrants and 4,208,618 for natives age 16 and older in the employment regressions (353,449 and 2,789,414, respectively in the unemployment regressions). 
Table 3. Regression Estimates of the Sensitivity of Labor Market Outcomes among Immigrants and Natives to the State Business Cycle

\begin{tabular}{lcl} 
& Immigrants & Natives \\
\hline Employed & & \\
All & $0.297^{* *}$ & $0.130^{* *}$ \\
No high school diploma & $(0.068)$ & $(0.036)$ \\
& $0.255^{*}$ & 0.072 \\
High school diploma only & $(0.106)$ & $(0.117)$ \\
& $0.261^{* *}$ & $0.129^{*}$ \\
Some college & $(0.091)$ & $(0.057)$ \\
& $0.434^{*}$ & 0.071 \\
Bachelor's degree & $(0.183)$ & $(0.038)$ \\
& $0.437^{* *}$ & $0.154^{* *}$ \\
Unemployed & $(0.090)$ & $(0.049)$ \\
All & & \\
& & \\
No high school diploma & $-0.445^{* *}$ & $-0.231^{* *}$ \\
& $(0.059)$ & $(0.028)$ \\
High school diploma only & $-0.605^{* *}$ & $-0.331^{* *}$ \\
Some college & $(0.133)$ & $(0.102)$ \\
& $-0.481^{* *}$ & $-0.285^{* *}$ \\
Bachelor's degree & $(0.151)$ & $(0.038)$ \\
& $-0.341^{* *}$ & $-0.197^{* *}$ \\
& $(0.070)$ & $(0.028)$ \\
& $-0.320^{* *}$ & $-0.142^{* *}$ \\
& $(0.061)$ & $(0.036)$ \\
\hline
\end{tabular}

$* p<0.05 ; * * p<0.01$

Note: Shown are estimated coefficients on the growth rate of real state personal income in linear probability regressions. The samples for the top panel are the population age 16 and older for all or age 25 and older for education groups. The samples in the bottom panel are the labor force age 16 and older for all or age 25 and older for education groups. Each entry is from a separate regression. Regressions also include a linear time trend and its square, a quartic in age, an indicator for female, and state and quarter indicator variables. The (unweighted) number of observations is 533,582 for immigrants and 4,208,618 for natives age 16 and older in the employment regressions (353,449 and 2,789,414, respectively in the unemployment regressions). 